\title{
Gated-Communities in South Africa's Urban Areas 20 Years into Democracy: Old Wine in Newly Designed Bottles?
}

\author{
MS Tlou Ramoroka \\ Lecturer, Department of Development Planning and Management, University of Limpopo \\ Email: Millicent.Ramoroka@ul.ac.za
}

\section{Doi:10.5901/mjss.2014.v5n15p106}

\begin{abstract}
This paper theoretically argues that urban settlement planning vested in gated-communities for "security reasons" in a democratic South Africa's towns and cities, still perpetuates the past spatial legacies of apartheid urban settlement planning model. Of late, the gated-community settlement planning model has been adopted in most urban areas in South Africa. These gated-community urban settlements offer security as a private market commodity instead of a public good or right. In this way, the neoliberal urban security governance appears to provide justification for the renewed urban displacement, fragmentation, distortion, incoherence, inequality and inefficiency during South Africa's 20 years of democratic dispensation. Seemingly, this settlement planning to some extent, indirectly maintain the past spatial fragmentations and inequalities promoted by the apartheid government. The footprints are interspersed with gated-communities such as security villages and enclosed neighbourhoods, all sailing freely under the same old flag of "security", now formalized into official urban residential planning. The paper concludes that the gated-community settlement planning model perpetuates spatial, social and economic exclusions of the poorest sections of the urban population especially those who are residing in townships and the congested urban centres. Thus, this accepted urban settlement planning model which is considered as "new" is basically an old strategy which uses class instead of race as a decisive factor to separate people.
\end{abstract}

Keywords: Gated-communities; Urban areas; Democracy; South Africa

\section{Introduction}

The apartheid urban settlement planning model influenced the allocation of resources amongst and segregated the White, Black, Coloured and Indian populations in South Africa prior to 1994 (Davies, 1981; Simon, 1986; Massey, Condran \& Denton, 1987; Christopher, 1989, 1990, 1995, 1997, 2004; Freund, 2001; Charles, 2003; Oldfield, 2004; Donaldson \& Kotze, 2006; Lemanski, 2006; K'Akumu \& Olima, 2007). In order to address the negative consequences of the apartheid urban settlement planning model, post 1994 there has been a number of spatial initiatives with the intension to integrate the segregated populations especially in the same urban settlements (Christopher, 2004; Donaldson \& Kotze, 2006; Lemanski, 2006; K'Akumu \& Olima, 2007). However, South Africa's current land and housing market in towns and cities currently function in a class-based segregated set-up thereby limiting the poor from accessing most amenities, services and infrastructure (K'Akumu \& Olima, 2007; Ramoroka, 2013a). The popularly known settlement planning model dominant in South Africa's towns and cities which uses class as a decisive factor is the gated-community (Mabin \& Smit, 1997; Firman, 2000; Landman, 2002; Leisch, 2002, Borsdorf \& Hidalgo, 2008; Tanulku, 2012; Pacione, 2013; Ramoroka, 2013a). Apparently, this model formerly uses privatized space to separate the rich from the poor in towns and cities and the planning of these settlements is further integrated in and supported by some urban land-use planning policies (Borsdorf \& Hidalgo, 2008; Tanulku, 2012; Pacione, 2013; Ramoroka, 2013b). The same gated-communities offer security as a private market commodity rather than a public good or right thereby perpetuating the socio-economic inequalities between the rich and poor who are residing in towns and cities.

It is against this background that with the inclusion of this introduction, the paper consists of five sections. The second section discusses the apartheid urban settlement planning model which aims to explain the past urban settlement planning system in South Africa. In the third section, the post-apartheid urban settlement planning model specifically the gated-community is discussed. The section further explains the relationship between the apartheid and the current gatedcommunity urban settlement planning models. The fourth section explains how security governance in urban areas serves as an ingredient that perpetuates socio-economic exclusions which some were a result of the apartheid urban settlement planning model. The paper then concludes that the current urban settlement planning model interspersed with gated-communities such as security villages and enclosed neighbourhoods, does little to redress the past apartheid 
socio-economic inequalities but instead continues to fuel and support the inequalities.

\section{The Apartheid Urban Settlement Planning Model}

South Africa's apartheid urban settlement planning model has left the footprints of spatial, economic and social segregation in most towns and cities (Davies, 1981; Simon, 1986; Massey et al., 1987; Christopher, 1989, 1990, 1995, 1997, 2004; Freund, 2001; Charles, 2003; Oldfield, 2004; Donaldson \& Kotze, 2006; Lemanski, 2006). This urban settlement planning model was used as an effective tool to ensure segregation amongst the White, Black, Coloured and Indian populations (Freund, 2001; Charles, 2003; K'Akumu \& Olima, 2007). During the apartheid era, segregation was enforced to ensure that racial as well as ethnic mixing did not occur for social and economic reasons in favour of the White population (Christopher, 1997; K'Akumu \& Olima, 2007). The spatial residential segregation was part of the official urban development planning in the country. This segregation was also visible within churches, shopping centres, schools and other places which could be used to build social cohesion and stability amongst people and within communities (Christopher, 2004; Lemanski, 2006; K'Akumu \& Olima, 2007). As a result, South Africa's residential and social segregation was spatially informed and fixed in order to be able to achieve the goals associated with this segregation which were in favour of the White population (Freund, 2001; Charles, 2003; Donaldson \& Kotze, 2006; Lemanski, 2006). Thus, different ethnic groups had to be allocated land away from each other and more especially from the White populations who were mostly residing in urban centres.

The Group Areas Act (Act No. 41 of 1950) was used as an instrument to spatially segregate people living in urban areas according to their languages and the colour of their skins (RSA, 2001). Additionally, this act enforced the development of residential areas along racial and ethnic lines, thereby excluding the majority of the Black population from the social, economic and environmental benefits associated with this spatial planning (RSA, 2001). Thus, the resultant segregated urban settlement pattern was characterized by White urban areas surrounded by Black townships, sometimes called semi- or peri-urban, for their confused mix of urban and rural activities and characters (Lemon \& Clifford, 2005; Donaldson \& Kotze, 2006; K'Akumu \& Olima, 2007). The townships were used to house the labour force, specifically Blacks who were working for the Whites in town and city centres and suburbs while their families were left in disadvantaged rural areas away from infrastructure, amenities, services and economic opportunities (Massey et al., 1987; Christopher, 1997, 2004; Freund, 2001; Charles, 2003; Oldfield, 2004). The distances between the townships and the towns' and cities' centres were considered short distances for everyday commuting of the labour force. However, this spatial spread of the urban settlement carried significant costs for those who resided in townships due to daily commuting to the urban centres. Therefore, the apartheid settlement planning resulted in a system of unequal access to socioeconomic resources in most towns and cities (Christopher, 1990, 2004; RSA, 2001). Furthermore, this urban settlement planning model caused urban displacement, distortion, fragmentation, incoherence, inequality and inefficiency in towns and cities. The next section discusses gated-communities as a settlement planning model which was adopted after 1994 in South Africa's urban areas.

\section{Gated-Community Settlement Planning Model: Old Wine in New Bottles for a Democratic South Africa}

The gated-community settlement planning model is a phenomenon which originally emerged with a special function to differentiate amongst different lifestyles, prestige and security zone communities (Mabin \& Smit, 1997; Firman, 2000; Landman, 2002; Leisch, 2002; Borsdorf \& Hidalgo, 2008; Tanulku, 2012; Almatarneh, 2013; Hapsariniaty, Sidi, \& Nurdini, 2013; Pacione, 2013; Ramoroka, 2013a, 2013b; Kovács \& Hegedüs, 2014). Throughout history, towns and cities were built with walls to protect their citizens against intruders, aggressive parties, neighbouring states and criminals (Landman, 2004; Bénit-Gbaffou, 2008; Kovács \& Hegedüs, 2014; Güzey, 2014). Additionally, gated-community settlements were built in most developed countries to protect estates and to contain the leisure world especially of retirees (Low, 2001; Almatarneh, 2013; Gądecki, 2014). Ethnicity, geographic origin and religion have been other reasons for living separately within walls and fences in the past (Low, 2001; Leisch, 2002; Almatarneh, 2013; Smigiel, 2014). In most urban areas, the gated-community settlements started with the closing-off of streets with walls then followed by the construction of highrise apartment blocks (Borsdorf \& Hidalgo, 2008). These actions resulted in most public spaces being sectioned-off and only accessible to the few, especially the residents of the gated-community settlements (Landman, 2004; Ramoroka, 2013a, 2013c; Kovács \& Hegedüs, 2014; Gądecki, 2014). Then new residential areas were erected behind the high walls and fences together with the installation of sophisticated security measures (Rogers \& Sukolratanametee, 2009; Tanulku, 2012; Almatarneh, 2013; Hapsariniaty et al., 2013; Pacione, 2013; Güzey, 2014). The walls and fences are there to make sure that the undesirable elements cannot gain access into the settlements without permission (Borsdorf \& Hidalgo, 2008; 
Tanulku, 2012; Pacione, 2013; Ramoroka, 2013a, 2013c; Gądecki, 2014). However, there are residential areas surrounded by walls or fences with an open-gate and sometimes without security guards or booms (Rogers \& Sukolratanametee, 2009; Almatarneh, 2013; Ramoroka, 2013a, 2013c; Güzey, 2014). Even in these places, people respect that there is a boundary which they should not pass without permission (Leisch, 2002; Ramoroka, 2013a, 2013c).

The gated-community settlements in South Africa have been rightly taken into account in the towns' and cities' settlement planning (Borsdorf \& Hidalgo, 2008; Landman, 2004). Lately, most urban populations in the formal settlements are engaging in new forms of social and economic exclusions, which manifest through gated-communities which include security villages and enclosed neighbourhoods. These current gated-community settlements are similar to that of the European and Asian countries which are a mixture of community needs, modern design and capitalist imperatives (Leisch, 2002; Smigiel, 2014). The gated-community settlements are the results of class arrangements as opposed to race. Although conceived differently, the motive underlying the latest gated-communities is commonly "security concerns" (Leisch, 2002; Borsdorf \& Hidalgo, 2008; Rogers \& Sukolratanametee, 2009; Kotus \& Hlawka, 2010; Hapsariniaty et al., 2013; Ramoroka, 2013a, 2013c; Kovács \& Hegedüs, 2014; Gadecki, 2014). Security has always been the primary concern even in the past urban settlement planning however, the current gated community settlement planning has invoked it in an apparently less emotive and politically-inclined context (Donaldson \& Kotze, 2006; Tanulku, 2012; Pacione, 2013; Smigiel, 2014). Generally, most gated-community settlements contribute to socio-economic exclusions, changed traffic patterns and the privatization of what used to be public spaces, amenities, services and infrastructure (Landman, 2004; Borsdorf \& Hidalgo, 2008; Gądecki, 2014). Therefore, current urban settlement planning model vested in gated-communities for security reasons in a democratic South Africa's towns and cities still perpetuates the past spatial legacies of apartheid urban settlement planning even after 20 years of the democratic dispensation. The succeeding section argues that security governance in gated-communities is one of the ingredients which contribute to socioeconomic exclusions within South Africa's towns and cities.

\section{Security Governance in South Africa's Urban Areas: One of the Ingredients for Socio-Economic Exclusions}

Post 1994, there has been a major increase in the number of gated-communities within South Africa's towns and cities (Landman, 2002; Bénit-Gbaffou, 2008). Most of these gated-communities are a response of high urbanization rates which the latter is assumed to be accompanied by slums and high crime rates within the congested urban centres. BénitGbaffou (2008: 1937) asserted that "neighbourhood enclosures, use of CCTV cameras and patrolling guards reveal the level of fear prevailing in a number of suburbs". Furthermore, gated-communities may suggest that there are high levels of crime within the area and its surroundings, thus the walls and gates are meant to protect them from the criminals (Landman, 2004; Bénit-Gbaffou, 2008; Hapsariniaty et al., 2013; Ramoroka, 2013a, 2013c). Regardless of the fact that the provision of security in South Africa is one of the primary functions of the state and that equal access to security is a basic right for all the citizens, the privatization of security services in urban areas especially within gated-communities tends to be dominant (Bénit-Gbaffou, 2008; Paasche, 2013). In gated-communities, financial contributions towards security services are compulsory, paid by the residents as part of the monthly corporate charges. The financial contributions are in addition to the rates and taxes paid to the municipality and other service providers (Bénit-Gbaffou, 2008; Paasche, 2013; Smigiel, 2014). These compulsory contributions allow wealthy residents to contribute to their own security and to upgrade other separate locally-based urban services, amenities and infrastructure thereby excluding the poor from the benefits associated with the logistical arrangements in gated-communities. Additionally, these gatedcommunities in urban areas contribute to growing inequalities in terms of provision of security (Samara, 2010; Paasche, 2013).

The different forms of privatization of amenities, services and infrastructure in urban areas results in increasing levels of inequalities due to their limited access or lack thereof (Bénit-Gbaffou, 2008; Paasche, 2013; Ramoroka, 2013a, 2013b, 2013c; Zimmerman, 2014). Privatization as a result of neoliberal governance leads to the unbundling of services creating socio-economic inequalities and limiting state's capacity to control the effects of such services (Bénit-Gbaffou, 2008; Hapsariniaty et al., 2013; Paasche, 2013; Zimmerman, 2014). The provision of security in most towns and cities is also privatized leaving the majority of the poor population unprotected. The rise of privatizing security has adverse effects on the state's capacity to perform its core functions in this regard (Bénit-Gbaffou, 2008). Thus, democracy is accompanied by new challenges which are informing the form of security provisions in the country (Bénit-Gbaffou, 2008; Borsdorf \& Hidalgo, 2008; Rogers \& Sukolratanametee, 2009; Kotus \& Hlawka, 2010; Samara, 2010; Paasche, 2013). The current provision of security results in the participation of non-state actors which perpetuates highly unequal security systems that encourages socio-economic exclusions within South Africa's urban areas (Bénit-Gbaffou, 2008; Zimmerman, 2014). Additionally, these security exclusions create the impression that poverty in towns and cities is 
associated with crime. As a result, there seem to be high levels of crime in affluent urban areas due to private security services offered within gated-communities which the majority of the urban poor cannot afford (Paasche, 2013; Zimmerman, 2014). In a democratic state like South Africa, gated-communities symbolize the continuation of the apartheid urban settlement planning even though the current setting is based on class (Landman, 2004; Bénit-Gbaffou, 2008; Samara, 2010).

The neoliberal democratic governance of security suggests that there is a relationship between security and the developments of gated-communities in South Africa's towns and cities. Furthermore, this relationship explains the interests and new patterns of attraction to gated-communities for residing, investing and consuming in urban areas. These gated-community urban settlements offer security as a private market commodity rather than a public good or right, as a result, the commodity can only be afforded by the rich people (Paasche, 2013; Zimmerman, 2014). Seemingly, the neoliberal urban security governance appears to provide justification for renewed urban displacement, fragmentation, distortion, incoherence, inequality and inefficiency in urban areas regardless of the 20 years of the democratic dispensation in South Africa. This neoliberal governance of security in urban areas excludes the poor from the benefits associated with the types of settlements, amenities, services and infrastructure that the rich have access to. The poor are left with limited access to security services which in most cases depend on the access to and availability of police officers as they cannot afford to pay for private security services. Accordingly, the neoliberal governance of security in urban areas contributes to the socio-economic exclusions which were framed during the apartheid era. However, the current exclusions are based on class using "security" to justify the planned gated-community settlements as opposed to race which was used during the apartheid era.

\section{Conclusion}

This paper has theoretically shown that the current urban settlement planning model vested in gated-communities such as security villages and neighbourhood enclosures is doing little to redress the socio-economic exclusions which were introduced during the apartheid era. The paper further revealed that the justification for the developments of gatedcommunities as for "security reasons" is still the same as the one which was used during apartheid era. As the paper indicated, race was used as an element to separate people in urban areas however; currently the separation is classbased. Thus, the neoliberal governance of security in urban areas separates the poor from the rich population which was one of the objectives of the apartheid settlement planning. Security governance in urban areas suggest that the rich do not trust the poor as the physical and human barriers are meant to restrict them access to their well developed areas. This paper acknowledges that South Africa's democratic spatial development planning specifically in urban areas still fuels the socio-economic exclusions 20 years into democracy. The paper then recommends that in order to address the inequalities in towns and cities, spatial planning should integrate the needs of both the rich and the poor. The integration can be achieved through the promotion of mixed-land uses that allow for diversity within the gated-communities in order to be able to cater for the needs of various socio-economic groups. Accommodating various economic groups within the same spaces, will to some extend reduce the socio-economic exclusions which are the results of the separateness brought by $20^{\text {th }}$ century gated-communities. Furthermore, the integration of the different socio-economic groups will build social cohesion, stability and trust between the rich and the poor.

\section{References}

Almatarneh, R.T. (2013). Choices and changes in the housing market and community preferences: reasons for the emergence of gated communities in Egypt. Ain Shams Engineering Journal, 4,563-583.

Bénit-Gbaffou, C. (2008). Unbundled security services and urban fragmentation in post-apartheid Johannesburg. Geoforum, 39, 19331950.

Borsdorf, A. \& Hidalgo, R. (2008). New dimensions of social exclusion in Latin America: from gated communities to gated cities, the case of Santiago de Chile. Land Use Policy, 25, 153-160.

Charles, C.Z. (2003). The dynamics of racial residential segregation. Annual Review of Sociology, 29, 167-207.

Christopher, A.J. (1989). Apartheid within apartheid: an assessment of official intra-black segregation on the Witwatersrand, South Africa. Professional Geographer, 41(3), 328-336.

Christopher, A.J. (1990). Apartheid and urban segregation levels in South Africa. Urban Studies, 27, $421-440$.

Christopher, A.J. (1995). Segregation and cemeteries in Port Elizabeth, South Africa. The Geographical Journal, 161(1), 38-46.

Christopher, A.J. (1997). Racial land zoning in urban South Africa. Urban Studies, 14(4), 311-323.

Christopher, A.J. (2004). Linguistic segregation in urban South Africa, 1996. Geoforum, 35, 145-156. 
Davies, R.J. (1981). The spatial formation of the South African city. GeoJournal, 2, 59-72.

Donaldson, R. \& Kotze, N. (2006). Residential desegregation dynamics in the South African city of Polokwane (Pietersburg). Tijdschrift voor Economische en Sociale Geografie, 97(5), 567-582.

Firman, T. (2000). Rural to urban land conversion in Indonesia during boom and bust periods. Land Use Policy 17, 13-20.

Freund, B. (2001). Contrasts in urban segregation: a tale of two African cities, Durban (South Africa) and Abidjan (Côte d'Ivoire). Journal of Southern African Studies, 27(3), 527-546.

Gądecki, J. (2014). Reprint of "the wild west. The reality of everyday social relations in gated communities in Poland". Cities, 36, 193199.

Güzey, Ö. (2014). Neoliberal urbanism restructuring the city of Ankara: gated communities as a new life style in a suburban settlement. Cities, 36, 93-103.

Hapsariniaty, A.W., Sidi, B.D. \& Nurdini, A. (2013). Comparative analysis of choosing to live in gated communities: a case study of Bandung metropolitan area. Procedia-Social and Behavioural Sciences, 101, 394-403.

K'Akumu, O.A. \& Olima, W.H.A. (2007). The dynamics and implications of residential segregation in Nairobi. Habitat International, 31, 87-99.

Kotus, J. \& Hlawka, B. (2010). Urban neighborhood communities organized on-line - A new form of self-organisation in the Polish city? Cities, 27, 204-214.

Kovács, Z. \& Hegedűs, G. (2014). Gated communities as new forms of segregation in post-socialist Budapest. Cities, 36, $200-209$.

Landman, K. (2002). Transforming urban spaces in South Africa: The impact of enclosed neighbourhoods on urban future. Pretoria: CSIR Building and Construction Technology.

Landman, K. (2004). Gated communities in South Africa: The challenges for spatial planning and land use management. The Town Planning Review, 75(2), 151-172.

Leisch, H. (2002). Gated communities in Indonesia. Cities, 19(5), 341-350.

Lemanski, C. (2006). The impact of residential desegregation on social integration: evidence from a South African neighbourhood. Geoforum, 37, 417-435.

Lemon, A. \& Clifford, D. (2005). Post-apartheid transition in a small South African town: Interracial property transfer in Margate, KwazuluNatal. Urban Studies, 42, 7-30.

Low, S.M. (2001). The edge and the center: gated communities and the discourse of urban fear. American Anthropologist, 103(1), 45-58.

Mabin, A. \& Smit, D. (1997). Reconstructing South Africa's cities? The making of urban planning 1900-2000. Planning Perspectives, 12 , 193-223.

Massey, D.S., Condran, G.A., \& Denton, N.A. (1987). The effect of residential segregation on black social and economic well-being. Social Forces, 66(1), 29-56.

Oldfield, S. (2004). Urban networks, community organising and race: an analysis of racial integration in a desegregated South African neighbourhood. Geoforum, 35, 189-201.

Paasche, T.F. (2013). 'The softer side of security': the role of social development in Cape Town's policing network. Geoforum, 45, 259265.

Pacione, M. (2013). Private profit, public interest and land use planning-A conflict interpretation of residential development pressure in Glasgow's rural-urban fringe. Land Use Policy, 32: 61-77.

Ramoroka, T. (2013a) Building safer urban human settlements in South Africa: a case of the National Development Plan 2030. Journal of Public Administration, 48(2), 321-333.

Ramoroka, T. (2013b) Land use management policies and small businesses within South Africa's cities. In Delener, N., Fuxman, L., Lu, F.V. \& Rivera-Solis, L.E. (eds.). Globalizing Businesses for the Next Century: Visualizing and Developing Contemporary Approaches to Harness Future Opportunities. New York: GBATA.

Ramoroka, T. (2013c) Safety and fear of crime in built environments: role of municipalities and community participation in South Africa. In Sebola, M.P., Tsheola, J.P., Phago, K.G. \& Balkaran, S. (eds.). The Challenges of Local Government in South Africa. Pretoria: SAAPAM.

Republic of South Africa (RSA). (2001). White Paper on Spatial Planning and Land Use Management. Pretoria: Government Printers.

Rogers, G.O. \& Sukolratanametee, S. (2009). Neighborhood design and sense of community: Comparing suburban neighborhoods in Houston Texas. Landscape and Urban Panning, 92, 325-334.

Samara, T.R. (2010). Policing development: urban renewal as neo-liberal security strategy. Urban Studies, 47(1), 197-214.

Simon, D. (1986). The apartheid city. Area, 16, 60-62.

Smigiel, C. (2014). Reprint of "the production of segregated urban landscapes: a critical analysis of gated-communities in Sofia". Cities, 36, 182-192.

Tanulku, B. (2012). Gated communities: from "self-sufficient towns" to "active urban agents". Geoforum, 43, 518-528.

Zimmerman, P.R. (2014). The deterrence of crime through private security efforts: theory and evidence. International Review of Law and Economics, 37, 66-75. 